\title{
A Comprehensive Review of Inflammatory Bowel Disease Focusing on Surgical Management
}

\author{
Seung Hyuk Baik, Won Ho Kim ${ }^{1}$ \\ Departments of Surgery and ${ }^{1}$ Internal Medicine, Yonsei University College of Medicine, Seoul, Korea
}

\begin{abstract}
The two main diseases of inflammatory bowel disease are Crohn's disease and ulcerative colitis. The pathogenesis of inflammatory disease is that abnormal intestinal inflammations occur in genetically susceptible individuals according to various environmental factors. The consequent process results in inflammatory bowel disease. Medical treatment consists of the induction of remission in the acute phase of the disease and the maintenance of remission. Patients with Crohn's disease finally need surgical treatment in $70 \%$ of the cases. The main surgical options for Crohn's disease are divided into two surgical procedures. The first is strictureplasty, which can prevent short bowel syndrome. The second is resection of the involved intestinal segment. Simultaneous medico-surgical treatment can be a good treatment strategy. Ulcerative colitis is a diffuse nonspecific inflammatory disease that involves the colon and the rectum. Patients with ulcerative colitis need surgical treatment in $30 \%$ of the cases despite proper medical treatment. The reasons for surgical treatment are various, from life-threatening complications to growth retardation. The total proctocolectomy (TPC) with an ileal pouch anal anastomosis (IPAA) is the most common procedure for the surgical treatment of ulcerative colitis. Medical treatment for ulcerative colitis after a TPC with an IPAA is usually not necessary.
\end{abstract}

Keywords: Crohn disease; Ulcerative colitis; Inflammatory bowel diseases

\section{INTRODUCTION}

Inflammatory bowel disease was officially reported with the name of 'regional ileitis' in 1932 by Crohn et al. [1]. However, a disease which could be considered as Crohn's disease retrospectively was first reported in 1813 [2].

The two main diseases of inflammatory bowel disease are Crohn's disease and ulcerative colitis. Inflammatory bowel disease has a wide range of manifestations from acute to chronic in nature and a wide involvement of lesions from the mouth to the anus. Crohn's disease shows a typically transmural inflammatory nature and involves both the small intestine and the colon. Ulcerative colitis

Received: April 4, 2012 - Accepted: June 10, 2012

Correspondence to: Won Ho Kim, M.D.

Department of Internal Medicine, Yonsei University College of Medicine, 50 Yonsei-ro, Seodaemun-gu, Seoul 120-752, Korea

Tel: +82-2-2228-1951, Fax: +82-2-393-6884

E-mail:kimwonho@yuhs.ac

(C) 2012 The Korean Society of Coloproctology

This is an open-access article distributed under the terms of the Creative Commons Attribution NonCommercial License (http://creativecommons.org/licenses/by-nc/3.0) which permits unrestricted noncommercial use, distribution, and reproduction in any medium, provided the original work is properly cited. occurs in the colon, and the inflammatory nature is superficial and is confined to the mucosa or submucosa.

The etiology of inflammatory bowel disease is uncertain. Thus, epidemiologic studies have been performed to find the reason for inflammatory bowel disease. In the United States, Canada, and the United Kingdom, the prevalence rate is 300 to 400 per 100,000 population. However, in Japan and Singapore, the prevalence rate is smaller than it is in the Western countries. The prevalence rate of inflammatory bowel disease is 23 per 100,000 population in Japan, and 10 per 100,000 population in Singapore. Moreover, Africa and South America have relatively low prevalence rates compared to the Western countries [3-6].

In Korea, there is a lack of nationwide epidemiologic data for the prevalence rate of inflammatory bowel disease. Recently, Yang et al. [7] reported that the adjusted prevalence rate of inflammatory bowel disease was 30.87 per 100,000 population for specific urban regions in the area of Seoul. This datum was similar to the data for other Asian countries (Japan and Singapore). In the study of Yang et al. [7] the prevalence rate increased from 11.24 per 100,000 population during 1986 to 1990 to 30.87 per 100,000 population during 2001 to 2005 . Korea was developing and becoming urbanized during those study periods. These results imply that urbanization 
may be a risk factor for inflammatory bowel disease.

\section{PATHOGENESIS OF INFLAMMATORY BOWEL DISEASE AND MEDICAL TREATMENT}

According to epidemiologic studies, the etiologies of inflammatory bowel disease include not only genetic factors but also environmental factors. As environmental factors, enteric microbes, flagellin, diet and smoking have been recognized as etiologic factors. Smoking has been clearly considered as a definite etiologic factor for developing Crohn's disease de novo and for increased recurrence after surgical treatment [8]. Moreover, hygiene, diet and antibiotics have been considered as environmental factors [9].

Genetic factors have been a major research area to evaluate the pathogenesis of inflammatory disease. As a genetic predisposition, NOD2/CARD15, IL-23 receptor, OCTN 1 and 2, DLG5, HLA, ATG16L1 and others are considered [8, 10, 11]. NOD2/CARD15 was discovered in 2001. NOD2/CARD15 is on chromosome 16 and is expressed as a cytoplasmic protein. Its role is recognition of muramyl dipeptide, a component of the bacterial cell wall peptidoglycan, and activation of NF-kappa B, a potent second messenger involved in immune regulatory mechanisms [12]. Genetic mutation of NOD2 causes an abnormal recognition of commensal bacteria in the intestinal lumen. Then, the innate immune system is impaired. Subsequently, abnormal inflammation occurs in the intestinal wall and results in the destruction of the mucosa. However, this hypothesis covers only $25 \%$ of the pathogenesis of Crohn's disease in Caucasians. Moreover, ulcerative colitis is not related to the mutation of NOD2 [13].

Thus, current understanding of the pathogenesis of inflammatory disease is that abnormal intestinal inflammations occur in genetically susceptible individuals because of various environmental factors such as diet, hygiene and drugs. The consequent process results in inflammatory bowel disease [14].

Medical treatment consists of the induction of remission in the acute phase of the disease and maintenance of remission. The purpose of proper treatments is to prevent complications from both the disease itself and the long-term medical treatment and to improve the quality of life by symptom control and prevention of complications. These purposes can be achieved by precise medical treatments and proper use of surgical treatments.

Sulfasalazine and 5-aminosalicylates are the first line drugs for mild-to-moderate Crohn's disease. Metronidazole and ciprofloxacin can be used as additional medical treatments for perianal complications of Crohn's disease. However, side effects occur in 50\% of the patients who take metronidazole. The side effects of metronidazole are indigestion, metallic taste, reaction to alcohol, and peripheral neuropathy. Peripheral neuropathy can be irreversible and occurs in patients with long-term use of metronidazole. Ciprofloxacin can be as effective as 5-aminosalicylic acid for the remission of Crohn's disease [15]. Corticosteriods, biologic agents and immunomodulators can be used for moderate-to-severe Crohn's disease. Corticosteriods are effective for the induction of remission, but are not indicated for maintenance therapy in Crohn's disease.

Immunomodulators that are often used for the medical treatment of Crohn's disease are azathioprine (AZA), 6-mercaptopurine (6-MP) and methorexate (MTX). AZA and 6-MP are useful for maintaining remission, and MTX can be used for the induction of remission. Infliximab is a tumor necrosis factor, an antagonist as a biologic agent, and is effective in both the induction of remission and the maintenance of remission. Especially, infliximab is effective in fistulizing Crohn's disease [16-18].

Sulfasalazine and 5-aminosalicylates are the first line agents for the induction of remission in mild-to-moderate ulcerative colitis, like Crohn's disease. In the treatment of ulcerative colitis, corticosteroids can be used for the induction of remission. AZA and 6-MP are used if the disease is persistently active and steroid refractory. Infliximab is the only biologic agent that is effective in treating ulcerative colitis and can be used for both the induction of remission and the maintenance of remission in patients with moderateto-severe ulcerative colitis [19]. Cyclosporin and infliximab can be used as rescue therapy for severe steroid-refractory ulcerative colitis [20].

\section{SURGICAL MANAGEMENT OF INFLAMMATORY BOWEL DISEASE}

\section{Crohn's disease}

Patients with Crohn's disease finally need surgical treatment in $70 \%$ of the cases and will require re-operations in 30 to $70 \%$ of the cases [21, 22]. The first line of treatment has been proper medical treatment because of its chronic inflammatory nature. However, medical treatment alone cannot manage the entire prolonged course of Crohn's disease. Surgical intervention is a critical and mandatory treatment option to manage complicated Crohn's disease. Indications of surgery for Crohn's disease are hemorrhage, intestinal perforation, intestinal obstruction and abscess. These indications usually need emergent operations in cases with severe colitis. Indications for an elective operation are a neoplasm from Crohn's disease, complications that have a chronic nature, growth retardation, and failed medical treatments. Failed medical treatments can be divided into non- or limited-responsive disease in the following situations: the patient's not being able to endure the symptoms related to Crohn's disease, the existence of problematic complications related to the medications for Crohn's disease, and the patient's poor compliance with the medication.

\section{Surgery options}

The main surgical options for Crohn's disease are divided into two surgical procedures. The first is strictureplasty, which can prevent short bowel syndrome. The second is resection of the involved intestinal segment. Both procedures can be performed using the 
open or the laparoscopic approach. Strictureplasty cannot be performed for patients with active Crohn's disease, phlegmon, septic fistulas, and duodenal strictures. Moreover, if the stricture site is a previous anastomosis site and recurrence occurs within 12 months of the previous operation, strictureplasty is not a proper surgical treatment option [23-26]. Perforation and severe malnutrition (albumin $<2.0 \mathrm{~g} / \mathrm{dL}$ ) are also contraindications of strictureplasty [23]. Without these contraindications, if the length of the remaining bowel is anticipated to be smaller than 1 to $2 \mathrm{~m}$, strictureplasty should be considered to avoid short bowel syndrome [27].

Many methods are used to perform strictureplasty. The most common method is the Heineke-Mikulicz strictureplasty. This method is a relatively easy method and can be adopted effectively by the general surgeon because it is the original surgical procedure for the treatment of duodenal peptic ulcer disease. The HeinekeMikulicz strictureplasty is appropriate for a short segment stricture $(<10 \mathrm{~cm})[28,29]$. A longitudinal enterotomy is performed along the stricture segment beyond $2 \mathrm{~cm}$. Then, primary closure is performed in a vertical direction. This method of closure permits a proper lumen after the operation.

Other strictureplasties similar to the Heineke-Mikulicz strictureplasty are the Judd stictureplasty and the Moskel-Walske-Neumayer strictureplasty. If a fistulous opening exists in the segment of a stricture, the Judd strictureplasty is performed. In this procedure, the fistulous opening is first excised. Then, a longitudinal entrotomy is performed horizontally across the excised fistulous opening, and primary repair is performed in the same manner as in the Heineke-Mikulicz strictureplasty. In the Moskel-WalskeNeumayer strictureplasty, a Y-shaped enterotomy is performed horizontally with the strictured segment. Closure of the Y-shaped enterotomy is similar to the Heineke-Mikulicz strictureplasty. These types of strictureplasties are for short segment strictures $(<10 \mathrm{~cm})$ [30].

If the length of the strictured segment is longer than $10 \mathrm{~cm}$ and shorter than $25 \mathrm{~cm}$, intermediate strictureplasties are proper surgical options. These procedures are the Finney strictureplasty and the Jaboulay strictureplasty. In the Finney strictureplasty, the strictured segment is folded into a $U$ shape, an enterotomy is performed along the folded $U$ shape segment, and a side-to-side anastomosis is performed [30-32]. If the enterotomy is linear at both sides without a connection and side-to-side anastomosis is done, the method is called a Jabloulay strictureplasty [29].

The Michelassi strictureplasty and the Poggioli stictureplasty are the surgical procedures for long strictured segments of the bowel $(>20 \mathrm{~cm})$. In the Michelassi strictureplasty, the first procedure is cutting the mid portion of the long strictured segment and then overlapping each strictured segment. Then, a side-to-side longitudinal enteroenterostomy is performed. This procedure is a sideto-side isoperistaltic strictureplasty. The Poggioli strictureplasty is a modified type of Michelassi strictureplasty. The difference is in the cutting area. The cutting area is the distal area of the strictured segment. This procedure is side-to-side isoperistatlic similar to the
Michelassi strictureplasty, and the diseased to the diseased-free enterostomy is different from the Michelassi strictureplasty.

The surgical field and condition of Crohn's disease is frequently difficult due to severe mesenteric inflammation, stricture, fistula, abscess and adhesion. In these conditions, surgeons prefer resection of the involved segment because of the possibility of rapid reactivation of Crohn's disease and anastomotic failure. However, the safety and the feasibility of strictureplasty have been noted [23, 24, 33-35].

Resection of the involved bowel is necessary if strictureplasty is not technically appropriate or indicated. Minimal invasive surgical procedures can be used for the surgery of Crohn's disease. Laparoscopic surgery is an available option for minimal invasive surgery. The benefits of laparoscopic surgery are a shorter hospital stay and better cosmetics compared to conventional open surgery. The median hospital stay of laparoscopic surgery was 5 days in the Maartense et al. [36] and the Milsom et al. [37] studies. In the Maartense et al. [36] study, the median hospital stay of open surgery was 7 days, and the hospital stay of laparoscopic surgery was shown to be significantly shorter than the hospital stay of conventional surgery. However, the difference in the length of stay between the two groups was not significant in the Milsom et al. [37] study. In the Milsom et al. [37] study, the median hospital stay was 6 days. The wound infection rates and the incidences of postoperative pneumonia were not different between the groups in these studies. Other studies have also reported on the safety and the feasibility of laparoscopic surgery $[38,39]$.

A valuable benefit of laparoscopic surgery is the shorter length of the skin incision. Crohn's disease patients are relatively younger than cancer patients. Thus, this cosmetic advantage of laparoscopic surgery can be valuable. However, the procedure of laparoscopic surgery is limited compared to conventional surgery. Laparoscopic surgery can be challenging if the surgical field has one or more of the following: advanced and severe mesenteric inflammation, an entero-enteric fistula, an entero-cutaneous fistula, or an abscess with severe fibrotic adhesion. Open conversion is frequently necessary in these situations. A delayed operation may result in the patient's losing the opportunity to receive minimally invasive surgery. This is unfortunate because minimally invasive surgery has better cosmetics after surgery compared to conventional open surgery. Besides laparoscopic surgery, single-port laparoscopic surgery (SILS) has been recently adopted in surgery for Crohn's disease. Laparoscopic surgery has multi-ports compared to SILS. Thus, SILS has better cosmetics than laparoscopic surgery, but more limitations during the procedure than laparoscopic surgery [40].

Robotic surgery is another option for minimally invasive surgery. It can be used for Crohn's disease because robotic surgery has been used for rectal cancer surgery and has the same concepts as laparoscopic surgery. However, adoption of robotic surgery is questionable due to the high cost of robotic surgery. To date, no report on robotic surgery for Crohn's disease has been found. 


\section{Perianal Crohn's disease}

In Crohn's disease, many pathologic anal lesions are related to Crohn's disease. These are perineal ulcerations, anal fissures, anal stenoses, anorectal abscesses, rectovaginal fistulas and perianal fistulas. These perianal diseases occur in up to $90 \%$ of Crohn's disease patients, and initial isolated perianal manifestation is observed in 10 to $15 \%$ of the patients $[41,42]$. Unusual perianal ulcers may occur in 1.9 to $5.1 \%$ of the patients with Crohn's disease [43].

Anal fissures occur at any location of the anus and are different from ordinary anal fissures, which occur at the posterior or anterior midline of the anus. The most common lesion is posterior (41\%), and multiple fissures occur in 32 to $33 \%$ of the patients. Lateral fissures occur in 9 to $20 \%$ of the patients. Anal pain is relatively less than it is for an ordinary anal fissure [41-43]. Conservative treatment is the first option. A lateral internal sphincterotomy can be applied to an intractable anal fissure [44].

Anal stenoses are common in patients with Crohn's disease. There are two etiologies of anal stenosis. The first is infection and inflammation of an intraluminal membrane or extramucosal fibrotic tissue. One finger dilatation or a Hegar dilator can be used for maintaining proper defecation in patients with severe anal stenosis. However, a proctectomy may be necessary in some severe cases [45].

Anorectal abscesses occur with an incidence of 23 to $62 \%$ in the natural history of Crohn's disease. They are a relatively common manifestation of Crohn's disease, and 70\% of the anorectal abscesses are related to perianal fistulas [43].

Rectovaginal fistulas are a problematic manifestation of Crohn's disease. They occur spontaneously in 3.5 to $23 \%$ of patients with Crohn's disease. A minimal symptomatic rectovaginal fistula may not need operative treatment. A symptomatic fistula without proctitis can be treated by local repair. A symptomatic fistula with severe proctitis usually needs a proctectomy. In this situation, local repair with a fecal diversion can be another treatment option [46, 47].

\section{Perianal fistulas}

Perianal fistulas are a very problematic condition that decreases the quality of life in Crohn's disease patients. The incidence of perianal fistulas in Crohn's disease patients is reported to be 14 to $56 \%$. Moreover, perianal fistulas can be the first clinical manifestation of Crohn's disease [48-50]. Clinical manifestations of perianal fistulas are prolonged pus drainage from an external opening of a perianal fistula. Perianal pain can accompany a perianal fistula because a perianal abscess can progress even though some part of the pus is drained through an external opening. In this situation, proper abscess drainage is usually necessary.

A conventional fistulotomy or fistulectomy should be applied with great attention because the postoperative wound is usually unhealed. Bell et al. [51] reported that the median healing time was up to 2.6 years after the operation. Intersphincter fistulas and low transsphincter fistulas can be treated safely without a high risk of postoperative incontinence by using a fistulotomy [52]. Mid and high transsphincter fistulas should not be treated by using a fistulotomy or a fistulectomy due to postoperative incontinence. Postoperative fecal incontinence after a fistulotomy or a fistulectomy occurs in over $50 \%$ of the cases. In this situation, the loose seton procedure is the favored surgical option. Seton is the thread that goes into the external opening through the fistula tract and that goes out from the internal opening and is linked with both ends. There are two kinds of seton procedures. They are the loose seton and the cutting seton. The loose seton is a favored procedure for Crohn's disease patients. The seton materials are usually silk, nylon, rubber, silicon, etc. The function of the seton is to maintain proper pus drainage continuously and to prevent perianal abscess formation. Long-term drainage using a seton is necessary. Recurrence after a seton removal occurs in $39 \%$ of the cases. Thus, in some cases, permanent seton drainage is required $[53,54]$.

Mucosal advancement flaps can be used for complex fistulas. The success rates of mucosal advancement flaps have been reported to be 55 to $98 \%$ [55-60]. However, a high recurrence rate was reported. Mizrahi et al. [55] reported that recurrence after a muscosal advancement flap replacement was $57 \%$ in patients with Crohn's disease, with a follow-up period of 40.3 months.

Recently, adipose-derived stem cell implantation has been introduced as an experimental treatment option for perianal fistulas related to Crohn's disease. Garcia-Olmo et al. [61] reported that stem cell implantation in combination with fibrin glue was more effective than fibrin glue alone in patients with a suprasphinteric fistula and that it was shown to be safe and effective for the treatment of complex perianal fistulas. However, the number of cases in these studies was less than 13. Thus, large-scale prospective clinical trials are necessary to commonly adopt stem cell implantation as a treatment method for perianal fistulas related to Crohn's disease [62].

\section{Medical treatment}

Medical treatment of perianal Crohn's disease cannot be underestimated. Surgical treatments have limitations as mentioned above. Thus, simultaneous medico-surgical treatment can be a good treatment strategy. Antibiotics, anti-tumor necrosis factor-a antibody agent, and immunomodulators are main medical treatment agents. Antibiotics like metronidazole and ciprofloxacin are used. Metronidazole is an antibiotic that fights against anaerobic bacteria infection. Perianal fistulas in patients with Crohn's disease have a colonization of anaerobic bacteria. Because of this, metronidazole is the first drug treatment for Crohn's-disease-related perianal fistulas [63]. The treatment success rates for perianal fistulas in patients with Crohn's disease using metronidazole ranged from 34 to $83 \%$ [64-68]. However, discontinuation of metronidazole resulted in recurrence even though it had been administered long term ( 6 to 8 weeks) $[64,68]$. There are various side effects such as a metallic taste, glossitis, nausea and severe peripheral neuropathy with long-term use of metronidazole [66].

Ciprofloxacin is an alternative antibiotic to metronidazole. Cip- 
rofloxacin is a quinolone antibiotic and is effective against gramnegative bacteria. The side effects of ciprofloxacin are relatively less than those of metronidazole. However, complete closure of the perianal fistula is very rare, and recurrence occurs after discontinuation of ciprofloxacin [69].

Infliximab is not only an effective drug for the maintenance treatment for Crohn's disease but also can be used for the treatment of perianal fistulas in patients with Crohn's disease. Present et al. [16] reported that the closure of fistulas was noted in $46 \%$ of the cases after a median of 12 weeks [18]. Immunomodulators, such as tacrolimus, cyclosporine, and AZA can be used for medical treatment of perianal fistulas in patients with Crohn's disease. However, these immunomodulators have serious side effects, such as an opportunistic infection and reactivation of a latent infection, as with infliximab. Thus, long-term medical treatment only for perianal fistulas in patients with Crohn's disease is controversial [70, 71].

Surgical and medical treatments have some roles in the treatment of perianal fistulas in patients with Crohn's disease. However, the treatment results are not satisfactory, and there are limitations because of the surgical and the medical complications from those treatment modalities. Thus, there have been endeavors to find other treatment methods. Recently, biomaterials have been introduced for the treatment of perianal fistulas in patients with Crohn's disease. These biomaterials are fibrin glue, BioGlue, collagen-based tissue adhesives, and collagen plugs [72-76].

Initial experiences using fibrin glue were acceptable, with a high success rate of 60 to $85 \%$ [72, 77-82]. However, these success rates were not repeated in subsequent studies [72, 81-84]. Vitton et al. [85] reported that the closure of fistulas was observed in only $14 \%$ of patients 3 months after treatment. BioGlue reported a 50\% success rate in the treatment of Crohn's-related perianal fistulas. However, it may cause serious nerve injury [73]. Collagen-based tissue adhesives and collagen fistula plugs are relatively safe biomaterials compared to fibrin glue in terms of disease transmission because they are manufactured from porcine dermis [74]. Collagen-based tissue adhesive has limited data for the treatment of perianal fistulas in patients with Crohn's disease, and the success rate of the collagen fistula plug is from 24 to $87 \%[75,86]$.

\section{Intraabdominal pyogenic complications}

Intraabdominal abscesses or pelvic abscesses occur at some point in 10 to $30 \%$ of patients with Crohn's disease throughout the whole natural history of the disease [87-89]. Intraabdominal abscesses, which occur in patients with Crohn's disease, show a chronic nature, and simultaneously entero-enteric, entero-peritoneal and entero-cuataneous fistulas can occur. Even though these abscesses rarely cause an acute septic condition, adequate drainage is necessary. Definitive surgical resection of the involved bowel is the traditional standard surgical treatment after abscess drainage. However, because of the development of minimally invasive interventional treatment, the drainage-only procedure has been introduced as the proper treatment option for intraabdominal abscesses in patients with Crohn's disease [90-92]. However, the drainage of the abscess has limitations. One-third of the patients who underwent drainage of the abscess needed a second surgical treatment after a one-year followup [93]. Other studies have reported that interventional percutaneous drainage as the only treatment for an intraabdominal abscess is successful in only about $50 \%$ of Crohn's disease patients [91, 92, 94-99].

Neufeld et al. [93] reported that 13 patients who received percutaneous or surgical drainage procedures due to abdominal wall abscesses eventually needed resection of the involved bowel segment. They found that surgical resection was necessary despite initial adequate drainage and concluded that surgical resection of the diseased bowel segment should be the definitive treatment according to their experiences. Poritz and Koltun [100] suggested a multimodal combined treatment protocol that consisted of initial proper percutaneous drainage with antibiotic and steroid administration, followed by a planned resection with a primary anastomosis. They suggested that this protocol provided standard care for the treatment of intraabdominal abscesses in Crohn's disease patients.

\section{ULCERATIVE COLITIS}

Ulcerative colitis is a diffuse nonspecific inflammatory disease that involves the colon and the rectum. The depth of inflammation is confined to the mucosa and the submucosa, which is different from Crohn's disease, which shows transmural inflammation. Typical clinical manifestations are diarrhea, abdominal pain, fever, weight loss and hematochezia. Clinical manifestations show both an acute and a chronic nature. Moreover, clinical the spectrum ranges from inactive to fulminant disease and is dynamic, ranging from remission to exacerbation. Chronic clinical manifestations of ulcerative colitis can be divided into mild, moderate, and severe disease. Frequency of bowel movements, rectal bleeding, hemoglobin, ESR, body temperature and heart rate are used as parameters in categorizing the severity $[101,102]$.

The small bowel is not involved in ulcerative colitis. However, the diarrheal contents of the cecum can reflux into the terminal ileum; then, the terminal ileum becomes inflamed, which is called 'back-wash ileitis' and shows a reversible nature. Backwash ileitis should be differentiated from the ileitis of Crohn's disease.

Ulcerative colitis has extra-colonic manifestations. Asymptomatic parenchymal liver disease is the most common manifestation [103]. Fatty infiltration is observed in up to $50 \%$ of patients with ulcerative colitis, and liver cirrhosis can also be present in 3 to $4 \%$ of patients with ulcerative colitis $[104,105]$. Primary sclerosing cholangitis is another hepatobiliary manifestation of ulcerative colitis. Arthritis, ankylosing spondylitis, and sacroiliitis are extracolonic manifestations of the bone and joints. As dermatologic manifestations, erythema nodosum and pyoderma gangrenosum can be observed in both ulcerative colitis and Crohn's disease. Erythema nodosum occurs in 10 to $15 \%$ of patients with both ulcer- 
ative colitis and Crohn's disease. Pyoderma gangrenosum is rare, but serious [106].

Patients with ulcerative colitis need surgical treatment in $30 \%$ of the cases, despite proper medical treatment [107]. The reasons for surgical treatment are various, ranging from life-threatening complications to growth retardation. The indications for surgery can be divided into two categories, elective and emergency, according to the need for emergent surgery. Indicators of elective surgery are refractory disease status to medical treatment, complications and side effects of chronic medical treatment, intestinal dysplasia or mass lesion, colorectal cancer, severe extra-colonic manifestation, stricture formation and growth retardation. Among these indicators of elective surgery, in fact, refractory disease status for medical treatment is difficult to define. Patients can feel their status is medically intractable because of too much loss of their opportunities to perform everyday or valuable works in their lives due to symptoms related to ulcerative colitis even though the physician is still considering other medical treatment strategies. In this situation, elective surgery should be decided appropriately. Definitely, the converse situation also can occur. However, problematic complications and surgical treatment options should be provided to the patients and their families.

The overall prevalence rate of colorectal cancer is approximately $3.7 \%$ in patients with ulcerative colitis [108]. The risk of colorectal cancer rises rapidly 10 years after exposure to ulcerative colitis. The risk of colorectal cancer is $50 \%$ after 30 years of the disease and $75 \%$ after 40 years of the disease [109]. Colorectal cancer and highgrade dysplasia are clear indicators of surgery. Dysplasia is graded into high-grade dysplasia and low-grade dysplasia according to the degree of cytologic and architectural alteration $[110,111]$. Low-grade dysplasia is controversial due to its relatively low risk of cancer development compared to high-grade dysplasia. However, surgical treatment should be considered in young patients with ulcerative colitis who have a long life expectancy. Pathologic diagnosis of dysplasia is a very difficult task. Thus, at least two different experienced pathologists are necessary for the proper diagnosis of dysplasia [112].

Extra-colonic manifestations are indicators of elective surgery in patients with ulcerative colitis. Arthritis, uveitis, and iritis are improved favorably after a colectomy. However, primary sclerosing cholangitis, ankylosing spondylitis, and sacroilitis are not improved even though a colectomy is performed $[106,113]$.

Indicators of emergent surgery are a toxic megacolon, perforation, uncontrolled rectal bleeding, septic condition or fulminant disease activity despite intensive medical treatment. In an emergent situation, the standard surgical option is a subtotal colectomy with an end ileostomy. This procedure is technically easier than a total proctocolectomy (TPC) with an ileal J-pouch anal anastomosis, which is performed in an elective situation. A subtotal colectomy with an end ileostomy can achieve proper disease control for a septic condition due to toxic complications of ulcerative colitis. Moreover, a future restorative procedure is possible. However, if mas- sive bleeding is focused in the rectum, then a proctectomy is necessary. Laparoscopic or hand-assisted laparoscopic surgery is feasible and safe in this situation. However, in critically ill patients, adopting laparoscopic surgery is controversial because this surgical procedure significantly increases the duration of the operation $[114,115]$.

As elective surgical treatments, there are four main surgical options. The first is the TPC with a Brooke ileostomy, and the second is a TPC with an ileal pouch anal anastomosis (IPAA) (TPC with IPAA). An abdominal colectomy with an ileorectal anastomosis and a TPC with a continent ileostomy are the third and the fourth surgical options, respectively. A TPC with a Brooke ileostomy (primary maturation of the ileostomy) has been the 'golden standard surgical option' because the entire diseased colon and rectum can be removed with low complications compared to other surgical options [116]. The permanent ileostomy is a disadvantage though. The patient should be educated preoperatively about changes in the body image and lifestyle. Recently, indicators of this procedure are elderly patients, patients with distal rectal cancer, preoperative poor anal sphincter function, which anticipates poor functional outcomes after sphincter-saving surgery, and patients who accept this procedure after preoperative education [116].

An abdominal colectomy with an ileorectal anastomosis is the rectum and anal-sphincter-saving procedure. If the rectum is not diseased preoperatively, this procedure can be performed. However, regular postoperative colonoscopic examinations should be performed to detect dysplasia or rectal cancer in the remaining rectum. The risk of rectal cancer is approximately 5\% in 15 to 20 years [117]. Young patients who want to return to work or want to preserve their reproductive abilities are candidates for this procedure. However, if patients have inflammation of the rectum or compromised anal sphincter function, this procedure cannot be used. The continent ileostomy was introduced by Kock [118]. This procedure is a surgical solution for patients who do not wish to attach an ostomy appliance and who do not want a Brooke ileostomy. However, postoperative complications are problematic in this procedure. Vernava and Goldberg [119] reported that early complication rates were $23 \%$ and that late complication rates were $54 \%$. In that study, they categorized intraabdominal abscesses, peritonitis, suture line leakages, fistulas, small bowel obstructions, and stomal necrosis as early complications and valve dysfunction requiring another operation as a late complication. Thus, recently, the use of this procedure has been very rare.

TPC with IPAA is the most common procedure for surgical treatment of ulcerative colitis because the body image does not change and the anal route of defecation is preserved. TPC with IPAA has four phases: removal of the colon and rectum while sparing the pelvic nerve and the anal sphincter function and constructions of an ileal reservoir, an ileal reservoir anal anastomosis and diverting ileostomy. The diverting ileostomy is generally recommended even though fecal diversion cannot prevent anastomotic leakage because it can prevent severe septic complications due to a large amount 
of fecal leakage into the pelvic cavity $[120,121]$. The ileal reservoir is an ileal pouch, and there are several types of ileal pouches. The S pouch was introduced in 1978 by Parks and Nicholls [122], and the J pouch was described by Utsunomiya et al. [123] in 1980. Recently, the J pouch has been the ileal pouch most preferred by almost all surgeons [124].

Medical treatment for ulcerative colitis after a TPC with IPAA is not necessary. However, pouchitis can occur after the operation, and the incident rate of pouchitis is 7 to $59 \%$ [125-127]. Other pouch-related complications can occur, and these are anastomotic strictures, perianal fistulas, perianal abscesses, abdominal fistulas, abdominal or pelvic abscesses, and unsatisfactory function of the pouch. The incidence rates of these complications are 12 to $22 \%$ $[128,129]$.

Sexual and voiding dysfunctions may occur because pelvic nerve injury may occur during the proctectomy. Postoperative impotence occurs in 1 to $2 \%$ of the patients and retrograde ejaculation in 2 to $3 \%$ of the patients. Dyspareunia occurs in $7 \%$ of the patients and fecal leaks during sexual intercourse in $2 \%$ of the patients [130-132].

The most problematic complication, which decreases the quality of life, is the ileal pouch vaginal fistula. The incidence rate of the ileal pouch vaginal fistula is 4 to $12 \%$ [133-138]. The ileal pouch vaginal fistula can persist even though repeated surgical attempts for closure are performed. The success rate of surgical treatment of an ileal pouch vaginal fistula is approximately $50 \%$ in patients with an initial failure of surgery [139]. Moreover, Shah et al. [140] reported eventual pouch failure in $22 \%$ of the patients and persistent pouch-vaginal fistulas in $27 \%$ of the 60 female patients who had a pouch-vaginal fistula after an IPAA.

\section{INDETERMINATE COLITIS}

Indeterminate colitis is a third disease entity among the inflammatory bowel diseases and was introduced by a pathologist [141]. However, the definition of indeterminate colitis is still controversial. Moreover, it can be considered as a non-disease entity and has no specific diagnostic criteria. Generally, indeterminate colitis is defined as an inflammatory bowel disease when the diagnostic criteria of either ulcerative colitis or Crohn's disease cannot be matched. Clinical, endoscopic, radiologic and pathologic information should be evaluated for the diagnosis of indeterminate colitis. The portion of indeterminate colitis among inflammatory bowel diseases is about 5\%, and other studies have reported prevalence rates from 1 to $20 \%$ [142-145].

Clinical manifestations of indeterminate colitis are more severe than those of ulcerative colitis and Crohn's disease and are related to fulminant ulcerative colitis. In the surgical aspect, indeterminate colitis should be attended to because it has a higher tendency of a colectomy, postoperative complications, and pouch failure after an IPAA [146].

\section{CONFLICT OF INTEREST}

No potential conflict of interest relevant to this article was reported.

\section{ACKNOWLEDGMENTS}

This study was supported by a faculty research grant of Yonsei University College of Medicine (6-2011-0114). The authors acknowledge Mi Sun Park for her dedicated assistance with the manuscript editing.

\section{REFERENCES}

1. Crohn BB, Ginzburg L, Oppenheimer GD. Regional ileitis, pathologic and clinical entity. JAMA 1932;99:1323-9.

2. Combe C, Saunders W. A singular case of stricture and thickening of the ileum. Med Trans R Soc Med 1806;16-8.

3. Blanchard JF, Bernstein CN, Wajda A, Rawsthorne P. Small-area variations and sociodemographic correlates for the incidence of Crohn's disease and ulcerative colitis. Am J Epidemiol 2001;154: 328-35.

4. Ekbom A, Helmick C, Zack M, Adami HO. The epidemiology of inflammatory bowel disease: a large, population-based study in Sweden. Gastroenterology 1991;100:350-8.

5. Sonnenberg A, McCarty DJ, Jacobsen SJ. Geographic variation of inflammatory bowel disease within the United States. Gastroenterology 1991;100:143-9.

6. Loftus EV Jr, Schoenfeld P, Sandborn WJ. The epidemiology and natural history of Crohn's disease in population-based patient cohorts from North America: a systematic review. Aliment Pharmacol Ther 2002;16:51-60.

7. Yang SK, Hong WS, Min YI, Kim HY, Yoo JY, Rhee PL, et al. Incidence and prevalence of ulcerative colitis in the SongpaKangdong District, Seoul, Korea, 1986-1997. J Gastroenterol Hepatol 2000;15:1037-42.

8. Koltun WA. The future of surgical management of inflammatory bowel disease. Dis Colon Rectum 2008;51:813-7.

9. Montgomery SM, Ekbom A. Epidemiology of inflammatory bowel disease. Curr Opin Gastroenterol 2002;18:416-20.

10. Duerr RH, Taylor KD, Brant SR, Rioux JD, Silverberg MS, Daly $\mathrm{MJ}$, et al. A genome-wide association study identifies IL23R as an inflammatory bowel disease gene. Science 2006;314:1461-3.

11. Wellcome Trust Case Control Consortium. Genome-wide association study of 14,000 cases of seven common diseases and 3,000 shared controls. Nature 2007;447:661-78.

12. Ogura Y, Bonen DK, Inohara N, Nicolae DL, Chen FF, Ramos R, et al. A frameshift mutation in NOD2 associated with susceptibility to Crohn's disease. Nature 2001;411:603-6.

13. Chapman-Kiddell CA, Davies PS, Gillen L, Radford-Smith GL. Role of diet in the development of inflammatory bowel disease. Inflamm Bowel Dis 2010;16:137-51.

14. Lees CW, Satsangi J. Genetics of inflammatory bowel disease: 
implications for disease pathogenesis and natural history. Expert Rev Gastroenterol Hepatol 2009;3:513-34.

15. Colombel JF, Lemann M, Cassagnou M, Bouhnik Y, Duclos B, Dupas JL, et al. A controlled trial comparing ciprofloxacin with mesalazine for the treatment of active Crohn's disease. Groupe d'Etudes Thérapeutiques des Affections Inflammatoires Digestives (GETAID). Am J Gastroenterol 1999;94:674-8.

16. Present DH, Rutgeerts $P$, Targan S, Hanauer SB, Mayer L, van Hogezand RA, et al. Infliximab for the treatment of fistulas in patients with Crohn's disease. N Engl J Med 1999;340:1398-405.

17. Targan SR, Hanauer SB, van Deventer SJ, Mayer L, Present DH, Braakman T, et al. A short-term study of chimeric monoclonal antibody cA2 to tumor necrosis factor alpha for Crohn's disease. Crohn's Disease cA2 Study Group. N Engl J Med 1997;337: 1029-35.

18. Hanauer SB, Feagan BG, Lichtenstein GR, Mayer LF, Schreiber S, Colombel JF, et al. Maintenance infliximab for Crohn's disease: the ACCENT I randomised trial. Lancet 2002;359:1541-9.

19. Rutgeerts P, Sandborn WJ, Feagan BG, Reinisch W, Olson A, Johanns J, et al. Infliximab for induction and maintenance therapy for ulcerative colitis. N Engl J Med 2005;353:2462-76.

20. Lichtiger S, Present DH, Kornbluth A, Gelernt I, Bauer J, Galler $\mathrm{G}$, et al. Cyclosporine in severe ulcerative colitis refractory to steroid therapy. N Engl J Med 1994;330:1841-5.

21. Bernell O, Lapidus A, Hellers G. Risk factors for surgery and postoperative recurrence in Crohn's disease. Ann Surg 2000;231: 38-45.

22. Duepree HJ, Senagore AJ, Delaney CP, Brady KM, Fazio VW. Advantages of laparoscopic resection for ileocecal Crohn's disease. Dis Colon Rectum 2002;45:605-10.

23. Jobanputra S, Weiss EG. Strictureplasty. Clin Colon Rectal Surg 2007;20:294-302.

24. Roy P, Kumar D. Strictureplasty. Br J Surg 2004;91:1428-37.

25. Laureti S, Fazio VW. Obstruction in Crohn's disease: strictureplasty versus resection. Curr Treat Options Gastroenterol 2000; 3:191-202.

26. Ambe R, Campbell L, Cagir B. A comprehensive review of strictureplasty techniques in Crohn's disease: types, indications, comparisons, and safety. J Gastrointest Surg 2012;16:209-17.

27. Shaffer VO, Wexner SD. Surgical management of Crohn's disease. Langenbecks Arch Surg 2012 Feb 21 [Epub]. http://dx.doi. org/10.1007/s00423-012-0919-7.

28. Katariya RN, Sood S, Rao PG, Rao PL. Stricture-plasty for tubercular strictures of the gastro-intestinal tract. Br J Surg 1977;64: 496-8.

29. Lee EC, Papaioannou N. Minimal surgery for chronic obstruction in patients with extensive or universal Crohn's disease. Ann R Coll Surg Engl 1982;64:229-33.

30. Gaetini A, De Simone M, Resegotti A. Our experience with strictureplasty in the surgical treatment of Crohn's disease. Hepatogastroenterology 1989;36:511-5.

31. Nivatvongs S, Gordon PH. Crohn's disease. In: Gordon PH,
Nivatvongs S, editors. Principles and practice of surgery for the colon, rectum and anus. 2nd ed. St. Louis: Quality Medical; 1999. p. 907-74.

32. Kirat HT, Remzi FH. Finney and Jaboulay techniques. In: Wexner SD, Fleshman JW, editors. Colon and rectal surgery: abdominal operations. Philadelphia: Lippincott Williams \& Wilkins; 2012. p. $563-79$.

33. Roy P, Kumar D. Strictureplasty for active Crohn's disease. Int J Colorectal Dis 2006;21:427-32.

34. Tonelli F, Fedi M, Paroli GM, Fazi M. Indications and results of side-to-side isoperistaltic strictureplasty in Crohn's disease. Dis Colon Rectum 2004;47:494-501.

35. Uchino M, Ikeuchi H, Matsuoka H, Matsumoto T, Takesue Y, Tomita N. Long-term efficacy of strictureplasty for Crohn's disease. Surg Today 2010;40:949-53.

36. Maartense S, Dunker MS, Slors JF, Cuesta MA, Pierik EG, Gouma DJ, et al. Laparoscopic-assisted versus open ileocolic resection for Crohn's disease: a randomized trial. Ann Surg 2006;243: 143-9.

37. Milsom JW, Hammerhofer KA, Bohm B, Marcello P, Elson P, Fazio VW. Prospective, randomized trial comparing laparoscopic vs. conventional surgery for refractory ileocolic Crohn's disease. Dis Colon Rectum 2001;44:1-8.

38. Bergamaschi R, Haughn C, Reed JF 3rd, Arnaud JP. Laparoscopic intracorporeal ileocolic resection for Crohn's disease: is it safe? Dis Colon Rectum 2009;52:651-6.

39. Nguyen SQ, Teitelbaum E, Sabnis AA, Bonaccorso A, Tabrizian P, Salky B. Laparoscopic resection for Crohn's disease: an experience with 335 cases. Surg Endosc 2009;23:2380-4.

40. Rijcken E, Mennigen R, Argyris I, Senninger N, Bruewer M. Single-incision laparoscopic surgery for ileocolic resection in Crohn's disease. Dis Colon Rectum 2012;55:140-6.

41. Dietz DW, Milsom JW, Fazio VW. Crohn's anorectal disease. In: Michelassi FM, Milsom JW, editors. Operative strategies in inflammatory bowel disease. New York: Springer; 1999. p. 394-408.

42. McKee RF, Keenan RA. Perianal Crohn's disease: is it all bad news? Dis Colon Rectum 1996;39:136-42.

43. Singh B, McC Mortensen NJ, Jewell DP, George B. Perianal Crohn's disease. Br J Surg 2004;91:801-14.

44. Wolkomir AF, Luchtefeld MA. Surgery for symptomatic hemorrhoids and anal fissures in Crohn's disease. Dis Colon Rectum 1993;36:545-7.

45. Hughes LE. Clinical classification of perianal Crohn's disease. Dis Colon Rectum 1992;35:928-32.

46. Heyen F, Winslet MC, Andrews H, Alexander-Williams J, Keighley MR. Vaginal fistulas in Crohn's disease. Dis Colon Rectum 1989;32:379-83.

47. Allan A, Keighley MR. Management of perianal Crohn's disease. World J Surg 1988;12:198-202.

48. Schwartz DA, Pemberton JH, Sandborn WJ. Diagnosis and treatment of perianal fistulas in Crohn disease. Ann Intern Med 2001; 135:906-18. 
49. Kodner IJ, Fry RD. Inflammatory bowel disease. Clin Symp 1982;34:3-32.

50. Sugita A, Koganei K, Harada H, Yamazaki Y, Fukushima T, Shimada H. Surgery for Crohn's anal fistulas. J Gastroenterol 1995;30 Suppl 8:143-6.

51. Bell SJ, Halligan S, Windsor AC, Williams AB, Wiesel P, Kamm MA. Response of fistulating Crohn's disease to infliximab treatment assessed by magnetic resonance imaging. Aliment Pharmacol Ther 2003;17:387-93.

52. Morris J, Spencer JA, Ambrose NS. MR imaging classification of perianal fistulas and its implications for patient management. Radiographics 2000;20:623-35.

53. Williams JG, MacLeod CA, Rothenberger DA, Goldberg SM. Seton treatment of high anal fistulae. Br J Surg 1991;78:1159-61.

54. Faucheron JL, Saint-Marc O, Guibert L, Parc R. Long-term seton drainage for high anal fistulas in Crohn's disease: a sphinctersaving operation? Dis Colon Rectum 1996;39:208-11.

55. Mizrahi N, Wexner SD, Zmora O, Da Silva G, Efron J, Weiss EG, et al. Endorectal advancement flap: are there predictors of failure? Dis Colon Rectum 2002;45:1616-21.

56. Kodner IJ, Mazor A, Shemesh EI, Fry RD, Fleshman JW, Birnbaum EH. Endorectal advancement flap repair of rectovaginal and other complicated anorectal fistulas. Surgery 1993;114: 682-9.

57. Zimmerman DD, Delemarre JB, Gosselink MP, Hop WC, Briel JW, Schouten WR. Smoking affects the outcome of transanal mucosal advancement flap repair of trans-sphincteric fistulas. Br J Surg 2003;90:351-4.

58. Sonoda T, Hull T, Piedmonte MR, Fazio VW. Outcomes of primary repair of anorectal and rectovaginal fistulas using the endorectal advancement flap. Dis Colon Rectum 2002;45:1622-8.

59. Ortiz H, Marzo J. Endorectal flap advancement repair and fistulectomy for high trans-sphincteric and suprasphincteric fistulas. Br J Surg 2000;87:1680-3.

60. Gustafsson UM, Graf W. Excision of anal fistula with closure of the internal opening: functional and manometric results. Dis Colon Rectum 2002;45:1672-8.

61. Garcia-Olmo D, Herreros D, Pascual I, Pascual JA, Del-Valle E, Zorrilla J, et al. Expanded adipose-derived stem cells for the treatment of complex perianal fistula: a phase II clinical trial. Dis Colon Rectum 2009;52:79-86.

62. Guadalajara H, Herreros D, De-La-Quintana P, Trebol J, GarciaArranz M, Garcia-Olmo D. Long-term follow-up of patients undergoing adipose-derived adult stem cell administration to treat complex perianal fistulas. Int J Colorectal Dis 2012;27: 595-600.

63. West RL, Van der Woude CJ, Endtz HP, Hansen BE, Ouwedijk M, Boelens HA, et al. Perianal fistulas in Crohn's disease are predominantly colonized by skin flora: implications for antibiotic treatment? Dig Dis Sci 2005;50:1260-3.

64. Jakobovits J, Schuster MM. Metronidazole therapy for Crohn's disease and associated fistulae. Am J Gastroenterol 1984;79:
533-40.

65. Schneider MU, Laudage G, Guggenmoos-Holzmann I, Riemann JF. Metronidazole in the treatment of Crohn disease. Results of a controlled randomized prospective study. Dtsch Med Wochenschr 1985;110:1724-30.

66. Bernstein LH, Frank MS, Brandt LJ, Boley SJ. Healing of perineal Crohn's disease with metronidazole. Gastroenterology 1980; 79:357-65.

67. Schneider MU, Strobel S, Riemann JF, Demling L. Treatment of Crohn's disease with metronidazole (author's transl). Dtsch Med Wochenschr 1981;106:1126-9.

68. Brandt LJ, Bernstein LH, Boley SJ, Frank MS. Metronidazole therapy for perineal Crohn's disease: a follow-up study. Gastroenterology 1982;83:383-7.

69. Peppercorn MA. Is there a role for antibiotics as primary therapy in Crohn's ileitis? J Clin Gastroenterol 1993;17:235-7.

70. Sandborn WJ, Present DH, Isaacs KL, Wolf DC, Greenberg E, Hanauer SB, et al. Tacrolimus for the treatment of fistulas in patients with Crohn's disease: a randomized, placebo-controlled trial. Gastroenterology 2003;125:380-8.

71. Hanauer SB, Smith MB. Rapid closure of Crohn's disease fistulas with continuous intravenous cyclosporin A. Am J Gastroenterol 1993;88:646-9.

72. Cintron JR, Park JJ, Orsay CP, Pearl RK, Nelson RL, Sone JH, et al. Repair of fistulas-in-ano using fibrin adhesive: long-term follow-up. Dis Colon Rectum 2000;43:944-9.

73. de la Portilla F, Rada R, Leon E, Cisneros N, Maldonado VH, Espinosa E. Evaluation of the use of BioGlue in the treatment of high anal fistulas: preliminary results of a pilot study. Dis Colon Rectum 2007;50:218-22.

74. Shaker MA, Hindy AM, Mounir RM, Geaisa KM. Competent closure of chronic oroantral fistula with Zenoderm. Egypt Dent J 1995;41:1237-42.

75. Johnson EK, Gaw JU, Armstrong DN. Efficacy of anal fistula plug vs. fibrin glue in closure of anorectal fistulas. Dis Colon Rectum 2006;49:371-6.

76. Ellis $\mathrm{CN}$. Bioprosthetic plugs for complex anal fistulas: an early experience. J Surg Educ 2007;64:36-40.

77. Patrlj L, Kocman B, Martinac M, Jadrijevic S, Sosa T, Sebecic B, et al. Fibrin glue-antibiotic mixture in the treatment of anal fistulae: experience with 69 cases. Dig Surg 2000;17:77-80.

78. Sentovich SM. Fibrin glue for all anal fistulas. J Gastrointest Surg 2001;5:158-61.

79. Lindsey I, Smilgin-Humphreys MM, Cunningham C, Mortensen NJ, George BD. A randomized, controlled trial of fibrin glue vs. conventional treatment for anal fistula. Dis Colon Rectum 2002; 45:1608-15.

80. Hjortrup A, Moesgaard F, Kjaergard J. Fibrin adhesive in the treatment of perineal fistulas. Dis Colon Rectum 1991;34:752-4.

81. Abel ME, Chiu YS, Russell TR, Volpe PA. Autologous fibrin glue in the treatment of rectovaginal and complex fistulas. Dis Colon Rectum 1993;36:447-9. 
82. Venkatesh KS, Ramanujam P. Fibrin glue application in the treatment of recurrent anorectal fistulas. Dis Colon Rectum 1999;42: 1136-9.

83. Loungnarath R, Dietz DW, Mutch MG, Birnbaum EH, Kodner IJ, Fleshman JW. Fibrin glue treatment of complex anal fistulas has low success rate. Dis Colon Rectum 2004;47:432-6.

84. Park JJ, Cintron JR, Orsay CP, Pearl RK, Nelson RL, Sone J, et al. Repair of chronic anorectal fistulae using commercial fibrin sealant. Arch Surg 2000;135:166-9.

85. Vitton V, Gasmi M, Barthet M, Desjeux A, Orsoni P, Grimaud JC. Long-term healing of Crohn's anal fistulas with fibrin glue injection. Aliment Pharmacol Ther 2005;21:1453-7.

86. Lawes DA, Efron JE, Abbas M, Heppell J, Young-Fadok TM. Early experience with the bioabsorbable anal fistula plug. World J Surg 2008;32:1157-9.

87. Cellini C, Safar B, Fleshman J. Surgical management of pyogenic complications of Crohn's disease. Inflamm Bowel Dis 2010; 16:512-7.

88. Nagler SM, Poticha SM. Intraabdominal abscess in regional enteritis. Am J Surg 1979;137:350-4.

89. Keighley MR, Eastwood D, Ambrose NS, Allan RN, Burdon DW. Incidence and microbiology of abdominal and pelvic abscess in Crohn's disease. Gastroenterology 1982;83:1271-5.

90. Kim DH, Cheon JH, Moon CM, Park JJ, Han SY, Kim ES, et al. Clinical efficacy of nonsurgical treatment of Crohn's disease-related intraabdominal abscess. Korean J Gastroenterol 2009;53: 29-35.

91. Jawhari A, Kamm MA, Ong C, Forbes A, Bartram CI, Hawley PR. Intra-abdominal and pelvic abscess in Crohn's disease: results of noninvasive and surgical management. Br J Surg 1998; 85:367-71.

92. Garcia JC, Persky SE, Bonis PA, Topazian M. Abscesses in Crohn's disease: outcome of medical versus surgical treatment. J Clin Gastroenterol 2001;32:409-12.

93. Neufeld D, Keidar A, Gutman M, Zissin R. Abdominal wall abscesses in patients with Crohn's disease: clinical outcome. J Gastrointest Surg 2006;10:445-9.

94. Bernini A, Spencer MP, Wong WD, Rothenberger DA, Madoff RD. Computed tomography-guided percutane ous abscess drainage in intestinal disease: factors associated with outcome. Dis Colon Rectum 1997;40:1009-13.

95. Gervais DA, Hahn PF, O’Neill MJ, Mueller PR. Percutaneous abscess drainage in Crohn disease: technical success and shortand long-term outcomes during 14 years. Radiology 2002;222: 645-51.

96. Lambiase RE, Cronan JJ, Dorfman GS, Paolella LP, Haas RA. Percutaneous drainage of abscesses in patients with Crohn disease. AJR Am J Roentgenol 1988;150:1043-5.

97. Safrit HD, Mauro MA, Jaques PF. Percutaneous abscess drainage in Crohn's disease. AJR Am J Roentgenol 1987;148:859-62.

98. Sahai A, Belair M, Gianfelice D, Cote S, Gratton J, Lahaie R. Percutaneous drainage of intra-abdominal abscesses in Crohn's disease: short and long-term outcome. Am J Gastroenterol 1997; 92:275-8.

99. Ayuk P, Williams N, Scott NA, Nicholson DA, Irving MH. Management of intra-abdominal abscesses in Crohn's disease. Ann R Coll Surg Engl 1996;78:5-10.

100. Poritz LS, Koltun WA. Percutaneous drainage and ileocolectomy for spontaneous intraabdominal abscess in Crohn's disease. J Gastrointest Surg 2007;11:204-8.

101. Truelove SC, Witts LJ. Cortisone in ulcerative colitis; preliminary report on a therapeutic trial. Br Med J 1954;2:375-8.

102. Truelove SC, Witts LJ. Cortisone in ulcerative colitis; final report on a therapeutic trial. Br Med J 1955;2:1041-8.

103. Lupinetti M, Mehigan D, Cameron JL. Hepatobiliary complications of ulcerative colitis. Am J Surg 1980;139:113-8.

104. Bush A, Mitchison H, Walt R, Baron JH, Boylston AW, Summerfield JA. Primary biliary cirrhosis and ulcerative colitis. Gastroenterology 1987;92:2009-13.

105. Eade MN, Cooke WT. Hepatobiliary disease associated with ulcerative colitis. Postgrad Med 1973;53:112-8.

106. Levine JB, Lukawski-Trubish D. Extraintestinal considerations in inflammatory bowel disease. Gastroenterol Clin North Am 1995;24:633-46.

107. Langholz E, Munkholm P, Davidsen M, Binder V. Course of ulcerative colitis: analysis of changes in disease activity over years. Gastroenterology 1994;107:3-11.

108. Eaden JA, Abrams KR, Mayberry JF. The risk of colorectal cancer in ulcerative colitis: a meta-analysis. Gut 2001;48:526-35.

109. Devroede G. Risk of cancer in inflammatory bowel disease. In: Winawer SJ, Schottenfeld D, Sherlock P, editors. Colorectal cancer: prevention, epidemiology and screening. New York: Paven Press; 1980. p. 325-34.

110. Riddell RH, Goldman H, Ransohoff DF, Appelman HD, Fenoglio CM, Haggitt RC, et al. Dysplasia in inflammatory bowel disease: standardized classification with provisional clinical applications. Hum Pathol 1983;14:931-68.

111. Harpaz N, Polydorides AD. Colorectal dysplasia in chronic inflammatory bowel disease: pathology, clinical implications, and pathogenesis. Arch Pathol Lab Med 2010;134:876-95.

112. Spinelli A, Sampietro GM, Bazzi P, Sacchi M, Montorsi M. Surgical approach to ulcerative colitis: when is the best timing after medical treatment? Curr Drug Targets 2011;12:1462-6.

113. Cangemi JR, Wiesner RH, Beaver SJ, Ludwig J, MacCarty RL, Dozois RR, et al. Effect of proctocolectomy for chronic ulcerative colitis on the natural history of primary sclerosing cholangitis. Gastroenterology 1989;96:790-4.

114. Holubar SD, Larson DW, Dozois EJ, Pattana-Arun J, Pemberton JH, Cima RR. Minimally invasive subtotal colectomy and ileal pouch-anal anastomosis for fulminant ulcerative colitis: a reasonable approach? Dis Colon Rectum 2009;52:187-92.

115. Cima RR. Timing and indications for colectomy in chronic ulcerative colitis: surgical consideration. Dig Dis 2010;28:501-7.

116. Brooke BN. The management of an ileostomy, including its 
complications. Lancet 1952;2:102-4.

117. Hawley PR. Ileorectal anastomosis. Br J Surg 1985;72 Suppl: S75-6.

118. Kock NG. Intra-abdominal "reservoir" in patients with permanent ileostomy. Preliminary observations on a procedure resulting in fecal "continence" in five ileostomy patients. Arch Surg 1969;99:223-31.

119. Vernava AM 3rd, Goldberg SM. Is the Kock pouch still a viable option? Int J Colorectal Dis 1988;3:135-8.

120. Tjandra JJ, Fazio VW, Milsom JW, Lavery IC, Oakley JR, Fabre JM. Omission of temporary diversion in restorative proctocolectomy: is it safe? Dis Colon Rectum 1993;36:1007-14.

121. Williamson ME, Lewis WG, Sagar PM, Holdsworth PJ, Johnston D. One-stage restorative proctocolectomy without temporary ileostomy for ulcerative colitis: a note of caution. Dis Colon Rectum 1997;40:1019-22.

122. Parks AG, Nicholls RJ. Proctocolectomy without ileostomy for ulcerative colitis. Br Med J 1978;2:85-8.

123. Utsunomiya J, Iwama T, Imajo M, Matsuo S, Sawai S, Yaegashi K, et al. Total colectomy, mucosal proctectomy, and ileoanal anastomosis. Dis Colon Rectum 1980;23:459-66.

124. Heikens JT, de Vries J, Goos MR, Oostvogel HJ, Gooszen HG, van Laarhoven CJ. Quality of life and health status before and after ileal pouch-anal anastomosis for ulcerative colitis. Br J Surg 2012;99:263-9.

125. Mignon M, Stettler C, Phillips SF. Pouchitis: a poorly understood entity. Dis Colon Rectum 1995;38:100-3.

126. Stahlberg D, Gullberg K, Liljeqvist L, Hellers G, Lofberg R. Pouchitis following pelvic pouch operation for ulcerative colitis. Incidence, cumulative risk, and risk factors. Dis Colon Rectum 1996;39:1012-8.

127. Macafee DA, Abercrombie JF, Maxwell-Armstrong C. Pouchitis. Colorectal Dis 2004;6:142-52.

128. Schoetz DJ Jr, Coller JA, Veidenheimer MC. Can the pouch be saved? Dis Colon Rectum 1988;31:671-5.

129. Galandiuk S, Scott NA, Dozois RR, Kelly KA, Ilstrup DM, Beart RW Jr, et al. Ileal pouch-anal anastomosis. Reoperation for pouch-related complications. Ann Surg 1990;212:446-52.

130. Dozois RR, Kelly KA, Welling DR, Gordon H, Beart RW Jr, Wolff BG, et al. Ileal pouch-anal anastomosis: comparison of results in familial adenomatous polyposis and chronic ulcerative colitis. Ann Surg 1989;210:268-71.

131. Damgaard B, Wettergren A, Kirkegaard P. Social and sexual function following ileal pouch-anal anastomosis. Dis Colon Rectum 1995;38:286-9.
132. Oresland T, Fasth S, Nordgren S, Hulten L. The clinical and functional outcome after restorative proctocolectomy. A prospective study in 100 patients. Int J Colorectal Dis 1989;4:50-6.

133. Fazio VW, Ziv Y, Church JM, Oakley JR, Lavery IC, Milsom JW, et al. Ileal pouch-anal anastomoses complications and function in 1005 patients. Ann Surg 1995;222:120-7.

134. Groom JS, Nicholls RJ, Hawley PR, Phillips RK. Pouch-vaginal fistula. Br J Surg 1993;80:936-40.

135. Lee PY, Fazio VW, Church JM, Hull TL, Eu KW, Lavery IC. Vaginal fistula following restorative proctocolectomy. Dis Colon Rectum 1997;40:752-9.

136. Wexner SD, Rothenberger DA, Jensen L, Goldberg SM, Balcos EG, Belliveau P, et al. Ileal pouch vaginal fistulas: incidence, etiology, and management. Dis Colon Rectum 1989;32:460-5.

137. Paye F, Penna C, Chiche L, Tiret E, Frileux P, Parc R. Pouchrelated fistula following restorative proctocolectomy. Br J Surg 1996;83:1574-7.

138. O’Kelly TJ, Merrett M, Mortensen NJ, Dehn TC, Kettlewell M. Pouch-vaginal fistula after restorative proctocolectomy: aetiology and management. Br J Surg 1994;81:1374-5.

139. Heriot AG, Tekkis PP, Smith JJ, Bona R, Cohen RG, Nicholls RJ. Management and outcome of pouch-vaginal fistulas following restorative proctocolectomy. Dis Colon Rectum 2005;48:451-8.

140. Shah NS, Remzi F, Massmann A, Baixauli J, Fazio VW. Management and treatment outcome of pouch-vaginal fistulas following restorative proctocolectomy. Dis Colon Rectum 2003;46: 911-7.

141. Kent TH, Ammon RK, DenBesten L. Differentiation of ulcerative colitis and regional enteritis of colon. Arch Pathol 1970;89: 20-9.

142. Yu CS, Pemberton JH, Larson D. Ileal pouch-anal anastomosis in patients with indeterminate colitis: long-term results. Dis Colon Rectum 2000;43:1487-96.

143. Farmer M, Petras RE, Hunt LE, Janosky JE, Galandiuk S. The importance of diagnostic accuracy in colonic inflammatory bowel disease. Am J Gastroenterol 2000;95:3184-8.

144. Joossens S, Reinisch W, Vermeire S, Sendid B, Poulain D, Peeters $\mathrm{M}$, et al. The value of serologic markers in indeterminate colitis: a prospective follow-up study. Gastroenterology 2002;122:1242-7.

145. Marcello PW, Schoetz DJ Jr, Roberts PL, Murray JJ, Coller JA, Rusin LC, et al. Evolutionary changes in the pathologic diagnosis after the ileoanal pouch procedure. Dis Colon Rectum 1997;40:263-9.

146. Burakoff R. Indeterminate colitis: clinical spectrum of disease. J Clin Gastroenterol 2004;38(5 Suppl 1):S41-3. 